\title{
Exploring Gandhi's Fasting as a Symbol of Nonviolent Action
}

\author{
Arunesh Pathak \\ Technical Coordinator, The Peace Gong \\ Corresponding author: aruneshpathak.10@gmail.com
}

$\begin{array}{lll}\text { Received: } 01 \text { Feb., } 2019 \quad \text { Revised: } 05 \text { Apr., } 2019 & \text { Accepted: } 21 \text { May, } 2019\end{array}$

\begin{abstract}
Fasting has been an important element in different religious tradition and is linked to spirituality. Increasingly fasting is also associated with healthy living and well-being. But historically, fasting has also been associated with nonviolent protests. In modern times, Mahatma Gandhi took to fasting as a powerful symbol of nonviolent protest and action against the British empire. This chapter will explore in-depth Gandhi's fasting and the impact it made during the freedom struggle.
\end{abstract}

Keywords: Fasting, nonviolent action, satyagraha

Fasting has essentially been associated with religion and spirituality. When man turned to a supreme power and fear of the unknown, prayer and fasting became an integral part of man's quest to explore what is termed spirituality. All ancient cultures and religions practice fasting and prayer. In Indian classical Sanskrit texts, there are instances of penance and fasting. For example, in Kalidasa's "Kumara Sambhavam there is depiction of the rigorous penance and fasting of Parvati to win over Lord Shiva, the third in the Hindu Trinity. Observing fast or "Vrat" is part of Hindu faithful's belief system. There are days earmarked for it periodically like fasting on the eleventh lunar day of each of the lunar phases. There is a nine-day fasting coinciding with Ram Navami and women in north India fast for a whole day for the long life of their husbands.

All Semitic religions viz. Judaism, Christianity and Islam have annual fasting at different times and occasions. Judaism has several days of fast in a year including Yom Kippur. Christianity, especially the Catholic and Orthodox Churches observe fasts, the most important being the 40/50 day lent before Easter. Muslims fast during the month of Ramadan.
Fasting is an integral routine of Buddhist monks. Buddhist monks and nuns commonly do not eat each day after the noon meal. This is considered a disciplined regimen. Buddhist lay people fast during intensive meditation.

The practices of fast vary from faith to faith. Abstinence is the most important element in fasting. While some completely abstain from food, some others avoid certain favorite food items like meat, fish and dairy products; others avoid certain grains and beverages. In all fasting abstaining from what one considers most desirable including certain habits is the key.

All fasting whether it is religious, spiritual, for health or for anything else, always has a purpose or a reason. Those religiously or spiritually oriented do it for self purification or for communion with God or a supreme power. There are people who fast for health reasons like fighting obesity or for a more shapely body. There is a new tendency to do cyber fasting by abstaining from all cyber media for a fixed duration. This obviously is for people to escape from addiction to the cyber media and for reconnecting to the real world. 
Fasting or hunger strike adopted by Gandhi was one of the main components of Satyagraha, other elements being non-cooperation, civil disobedience and strike. Satyagraha is a combination of two Sanskrit words- 'Sathya' or truth and 'Agraha' or insistence / holding firmly to- or in other words holding firmly to truth. Gandhi himself defined the term in one of his articles in Young India thus," Satyagraha is literally holding on to Truth and it means, therefore, Truth force. It excludes the use of violence because man is not capable of knowing the absolute truth and, therefore, not competent to punish".

Gandhi wrote in the $15^{\text {th }}$ April issue of the Harijan, "The word Satyagraha is often most loosely used and is made to cover veiled violence. But as the author of the word, I may be allowed to say that it excludes every form of violence,veiled or unveiled, and whether in thought, word or deed. It is a breach of Satyagraha to wish ill to an opponent or to say a harsh word to him or of him with the intention of harming him. Satyagraha is gentle, it never wounds. It must not be the result of anger or malice. It is never fussy, never impatient, never vociferous. It is the direct opposite of compulsion. It was conceived as a complete substitute for violence."

In another observation Gandhi wrote, "since Satyagraha is one of the most powerful methods of direct action, Sathyagrahi exhausts all other means before he resorts to Satyagraha. He will, therefore, constantly and continually approach the constituted authority, he will appeal to public opinion, educate public opinion.... But when he has found the impelling call of the inner voice within him and launches out upon Satyagraha he has burnt his boats and there is no receding" (Young India, 20 $0^{\text {th }}$ October, 1927).

Gandhi directed his followers to understand the attributes of a Sathyagrahi; when and how it should be used as a weapon of protest. When one reads Gandhi, many of what he expected from those desirous of practicing Satyagraha may sound difficult and impractical. For example, writing in the $25^{\text {th }}$ March 1939 issue of the Harijan, he prescribed the following six requisites: -
1. He must have a living faith in God, for $\mathrm{He}$ is his only Rock.

2. He must believe in truth and nonviolence as his creed and therefore have faith in the inherent goodness of human nature which he expects to evoke by his truth and love expressed through his suffering.

3. He must be leading a chaste life and be ready and willing for the sake of his cause to give up his life and his possessions.

4. He must be a habitual Khadi-wearer and spinner. This is essential for India.

5. He must be a teetotaler and be free from the use of other intoxicants in order that his reason may be always unclouded and his mind constant.

6. He must carry out with a willing heart all the rules of discipline as may be laid down from time to time.

It was in South Africa that Gandhi launched Satyagraha. He had established the Phoenix Farm near Durban and trained his cadres in nonviolent Satyagraha or peaceful restraint." Phoenix Farm is considered the birthplace of Satyagraha. However, it was at the Tolstoy Farm, Gandhi's second camp in South Africa, where Satyagraha was molded into a weapon of protest. In September 1906, Gandhi organized the first Satyagraha campaign to protest against the Transvaal Asiatic ordinance that was considered against the local Indians. Again, in June 1907, he held Satyagraha against the Black Act" [www.indiatoday.in/education]. It was again at the Phoenix Farm in1913 that Gandhi fasted for a week for moral lapses at the settlement. The following year he undertook at the same venue 14 days fast for the similar reason. His fasts in India on a number of occasions were for problems in his Sabarmati Ashram and for communal harmony. Instead of celebrating his last birthday in 1947, he fasted [source: www.gandhi-manibhavan.org].

Gandhi articulated the nuances of fasting in the $18^{\text {th }}$ March, 1939 edition of the Harijan, "Fasting is a potent weapon in the Satyagrahaarmoury. It cannot be taken by everyone. Mere physical capacity to take it is no qualification for it. It is of no use without a 
living faith in God. It should never be a mechanical effort or a mere imitation. It must come from the depth of one's soul. It is therefore rare."

In a chapter on fasting in his Autobiography, "My Experiments with Truth", Gandhi writes, "Fasting can help to curb animal passions, only if it is undertaken with a view of self-restraint. Some of my friends have actually found their animal passions and palate stimulated as an after effect of fasts. That is to say that fasting is futile unless it is accompanied by an incessant longing for selfrestraint".

Gandhi also emphasized the preconditions for undertaking a fast: "There can be no room for selfishness, anger, lack of faith, or impatience in a pure fast....Infinite patience, firm resolve, singlemindedness of purpose, perfect calm, and no anger must of necessity be there. But since it is impossible for a person to develop all these qualities all at once, no one who has not devoted himself to following the laws of Ahimsa should undertake a Sathyagrahi fast" [Harijan, 13 ${ }^{\text {th }}$ October, 1940].

Mahtma Gandhi used fasting and Satyagraha as powerful weapons of nonviolent resistance. In 1932, when he was incarcerated in the Yarwada jail he started a hunger strike. It was to protest against the colonial government's decision to have separate political representation for the lowest castes or who were known as 'untouchables', for a period of seventy years. Gandhi who wanted emancipation of the lowest castes realized that such a separation of the electorate would perpetuate the obnoxious caste system and undertook a fast unto death in the jail itself. His six day fast was called off only after the British government reversed the decision.
Similarly, in the aftermath of the country's partition and the Hindu-Muslim riots that killed countless people, Gandhi began a fast, sadly his last, on January 12, 1948 in Delhi to persuade both the communities to eschew violence and restore peace. This fast had a salutary effect and a semblance of communal harmony was achieved.

The concept of Satyagraha and nonviolent resistance has been a source of inspiration to many countries and world leaders. Prominent among them is the American civil rights crusader Dr. Martin Luther King Jr. who adopted the methods of Satyagraha in his fight against racial discrimination by authorities in the United States. Nelson Mandela who successfully fought apartheid in South Africa and a host of political and thought leaders across the world have been inspired by Gandhi and his non violent philosophy.

Romain Rolland, French writer, mystic and Nobel Prize winner for literature in 1915, called Gandhi as "a saint and hero of Satyagraha. "In January 1932 Rolland wrote to Eduard Schenider, who was rather cynical about Mahatma Gandhi, quoting a letter he wrote to an English friend upset about events in India, "The great and ambitious Indian experiments with Satyagraha is the only chance open to the world of achieving this transformation of humanity without having recourse to violence. It is either Gandhi or Lenin! [Romain Rolland and Gandhi: Correspondence- Publications Division]. 
